\title{
Undetermined Explanation
}

National Cancer Institute

\section{Source}

National Cancer Institute. Undetermined Explanation. NCI Thesaurus. Code C159522.

A request to provide an explanation. 